Sharif University of Technology
Scientia Iranica
SCIENTIA
I RAN ICA
http://scientiairanica.sharif.edu

\title{
Effect of stress direction on the undrained monotonic and cyclic behavior of dense sands
}

\author{
F. Jafarzadeh ${ }^{a}$ and M. Zamanian ${ }^{\mathrm{b}, *}$ \\ a. Department of Civil Engineering, Sharif University of Technology, Tehran, Iran. \\ b. Department of Civil, Water, and Environmental Engineering, Shahid Beheshti University, Tehran, Iran. \\ Received 4 February 2017; received in revised form 8 July 2017; accepted 16 April 2018
}

\author{
KEYWORDS \\ Direction of major \\ principal stress; \\ Sand; \\ Pore water pressure; \\ Non-coaxiality; \\ Internal friction angle.
}

\begin{abstract}
Geotechnical design may be unsafe if the anisotropic behavior of soil is not considered. The behavior of anisotropic materials depends on the principal stresses and their directions. A detailed experimental programme was conducted to study the effect of stress direction on the monotonic and cyclic behavior of dense sand. A total of 20 undrained tests were performed at a constant mean confining stress $\left(\sigma_{0 m}^{\prime}\right)$, a constant intermediate principal stress ratio $\left(b=\left(\sigma_{2}-\sigma_{3}\right) /\left(\sigma_{1}-\sigma_{3}\right)\right)$, and principal stress directions $(\alpha)$. Two fine sands, Babolsar and Toyoura, were selected as the test materials. The isotropically consolidated specimens were prepared by the wet tamping technique. The results showed that the major principal stress direction had inconsiderable effect on the mobilized friction angle at steady state or phase transformation. The results showed that stress direction had a significant effect on the non-coaxiality between the principal strain increment direction and the principal stress direction. The soil fabric resulted in a significant non-coaxiality value before the peak shear strength. Increasing the octahedral shear strains decreased the non-coaxiality value due to the destruction of the soil particle interlock (soil fabric). The effect of stress direction on non-coaxiality and excess pore water pressure generation was also investigated.
\end{abstract}

(C) 2020 Sharif University of Technology. All rights reserved.

\section{Introduction}

The effect of major principal stress direction, $\alpha$, relative to the vertical axis on the monotonic and cyclic behavior of soil is relevant to the development of constitutive models. No comprehensive investigation into the effect of stress direction on the monotonic and cyclic behavior of soil has been published so far. In particular, the axes of the principal stress vary in many conventional test apparatuses and cannot be controlled during testing.

\footnotetext{
*. Corresponding author. Tel.: +98 2166022727 ; Fax: +982166014828

E-mail addresses: fardin@sharif.edu (F. Jafarzadeh); m_zamanian@sbu.ac.ir (M.Zamanian)
}

However, laboratory tests such as simple shear test, directional cell test, and torsional hollow cylinder test are able to control the direction of the principal axes of stress [1-7]. The hollow cylinder apparatus is a widely used device that can be used to investigate the anisotropic behavior of soil [5,6,8-10]. A brief review of this apparatus can be found in Hight et al. [7].

The impact of anisotropy on the behavior of sand has long been recognized [11,12]. Anisotropy represents any directional dependence in mechanical characteristics. Many research works have shown that the anisotropy was one of the most important parameters influencing soil behavior [11-22]. Casagrande and Carillo [23] observed that soils exhibited two types of anisotropy (i.e., inherent and induced anisotropies). During the deposition process, the soil particles tend to adopt a stable position. The soil masses are formed 
depending on particle shape, voids, type of deposition, spatial arrangement, and associated contact. This will lead to an initial anisotropy in the fabric of granular soils, defined as inherent or fabric anisotropy. The inherent anisotropy will cause the response of soil to be dependent on the orientation of principal stresses with reference to the depositional plane, $\alpha$. Numerous researchers have systematically investigated the fabric anisotropy of sand $[12,24-28]$. These research works showed that even perfectly rounded particles of granular soil exhibited inherent anisotropy due to the initial fabric. Moreover, the micro fabric studies confirmed that the particles might slide or move to adopt a stable structure, and inter-particle contact becomes preferentially oriented in the direction of deposition.

Changes in the magnitude and/or direction of stress exert(s) more anisotropy, which is defined as induced anisotropy. Induced anisotropy is formed by plastic deformation due to anisotropic external loading [23]. This definition provides a convenient distinction between inherent and induced anisotropy, which was later modified $[11,28-30]$ to involve previous strain as a part of the initial anisotropy and consider previously induced anisotropy as the initial anisotropy for subsequent conditions [22]. Many researchers have simulated some field loading situations such as wave loading on seabed deposits, multidirectional earthquake loading in level ground, and lateral cyclic loading on the soil behind retaining structures that involve the rotation of the principal stress directions during shear in the laboratory tests $[21,31,32]$. The stress paths associated with these loading situations may be classified as non-proportional loading $[18,21,33]$. However, the boundary conditions in these studies varied greatly, and the primary focus was on regenerating simple shear conditions rather than systematically investigating the effect of principal stress rotation and intermediate principal stress on the cyclic behavior of sands. These studies showed that the rotation of the principal axis could cause a liquefaction or strength reduction at a constant deviator stress.

Intermediate principal stress parameter, $b$, is not an influencing factor in the behavior of saturated sands. Many studies have reported that, for a given value of $\alpha$, the intermediate principal stress parameter, $b$, has little or no effect on the response of the sand (e.g., shear strength and internal friction angle) to monotonic and cyclic loading [29-40]. These studies and others have concluded that $\alpha$ has a significant influence on the response of the sands; however, the effect of $b$ on liquefaction and pore water pressure build-up has also been reported. Yang et al. [33] observed that, under otherwise identical conditions, specimens tested at $b=$ 0.0 exhibited greater resistance and the highest pore pressure build-up occurred at $b=1.0$. In general, the effect of intermediate principal stress on soil behavior is not significant when compared with the major principal stress direction, especially for dense sand.

The effects of major principal stress direction on the soils' behavior were investigated in the tests with the fixed direction of principal stress [41-48]. The main purpose of such experiments was to clarify uncertainties in the determination of the shear strength (e.g., steady state or peak shear strength), internal friction angle, and the non-coaxiality, defined as the no-coincidence between the principal stress axis and the principal strain rates axis. It has been found that, for the certain conditions of soil, the undrained behavior of sands is influenced by the shearing mode. Most of these research works were focused on the behavior of soils subjected to the monotonic loading. Therefore, more undrained tests should be performed to clarify the effects of principal stress direction on the response of soils under cyclic loading. To achieve this goal, a systematic program consisting of 20 undrained monotonic and cyclic torsional shear tests was performed on dense Babolsar and Toyoura sands under fixed major principal stress, $\alpha$. The specimens were prepared by a wet tamping technique. The influences of principal stress direction on the soil responses were isolated, while other parameters (e.g., construction technique, relative density, and confining stress) were held constant. The applied torsional shear apparatus was able to control both the direction and magnitude of principal stresses. By using this device, which allows for the creation of three different principal stresses, it is possible to apply continuous controlled increments and/or rotations of principal stresses in the vertical plane of the hollow cylinder specimen. The stressstrain behavior was measured carefully to make a reliable analysis of the soil behavior. This paper aims to study the undrained anisotropic response of sands under a fixed direction of the major principal stress. The soil behavior was investigated for a pattern of $\alpha$, varying from $10^{\circ}$ to $80^{\circ}$ (i.e., $\alpha=10^{\circ}, 30^{\circ}, 45^{\circ}, 60^{\circ}$, and $80^{\circ}$ ). Based on the experimental results, the effects of shearing mode and sand type are discussed.

The notation used throughout the paper is given in Table 1.

\section{Laboratory testing procedure}

\subsection{Torsion shear apparatus}

The closed-loop control system of the dynamic hollow cylinder apparatus (manufactured by Wykeham Farrance International Company) used in this study has five main components:

1. Hollow cylinder software;

2. A high-speed Data Acquisition System (DAS);

3. Servo valves; 
Table 1. List of notation.

\begin{tabular}{|c|c|}
\hline Symbol & Physical quantity \\
\hline$b$ & Intermediate principal stress parameter $\left(b=\left(\sigma_{2}-\sigma_{3}\right) /\left(\sigma_{1}-\sigma_{3}\right)\right)$ \\
\hline$\alpha$ & Inclination of major principal stress to vertical \\
\hline$\alpha_{d \varepsilon}$ & Inclination of major principal strain increment to vertical \\
\hline$H$ & Hollow cylinder specimen length \\
\hline$H C A$ & Hollow Cylinder Apparatus \\
\hline$\sigma_{0 m}^{\prime}$ & Initial effective mean normal stress \\
\hline$\zeta$ & $\begin{array}{l}\text { Non-coaxiality defined as non-coincidence between the principal stress } \\
\text { and strain increment directions, } \zeta=\alpha-\alpha_{d \varepsilon}\end{array}$ \\
\hline$q$ & Deviator stress \\
\hline$\varepsilon_{z}, \varepsilon_{\theta}, \varepsilon_{r}$ & Vertical, tangential, and radial normal strains \\
\hline$\varepsilon_{1}$ & Major principal strain \\
\hline$\tau_{z \theta}, \tau_{\theta z}$ & Circumferential shear stresses \\
\hline$\sigma_{z}, \sigma_{r}, \sigma_{\theta}$ & Axial, radial, and circumferential normal stresses \\
\hline$\sigma_{1}, \sigma_{2}, \sigma_{3}$ & Major, intermediate, and minor total principal stresses \\
\hline$\sigma_{1}^{\prime}, \sigma_{2}^{\prime}, \sigma_{3}^{\prime}$ & Effective major, intermediate, and minor principal stresses \\
\hline$p_{i}$ and $p_{o}$ & Inner and outer confining pressures, respectively \\
\hline$r_{i}$ and $r_{o}$ & Inner and outer specimen radii, respectively \\
\hline$F_{v}$ & Vertical load \\
\hline$T$ & Torque applied to twist the hollow cylinder \\
\hline$l_{o}$ and $l_{i}$ & Changes in outside and inside radii, respectively \\
\hline$\Delta I_{v o l}$ and $\Delta V$ & Changes in volumes of the inner cell and the specimen, respectively \\
\hline$\Delta H_{L V D T}$ & Recorded change in the horizontal LVDT reading \\
\hline$r_{\text {measurement plate }}$ & Distance from the center to the radio wire cord of the pie-shaped measurement plate \\
\hline$\varphi_{\mu}^{\prime}$ & Interparticles sliding friction angle \\
\hline$\varphi_{g}^{\prime}$ & Geometrical interface friction angle \\
\hline$\varphi_{d}^{\prime}$ & Dilation angle \\
\hline$\varphi_{p}^{\prime}$ & Particle rearrangement or damage angle \\
\hline$\varphi_{m o b}^{\prime}$ & Mobilized friction angle \\
\hline$\varphi_{f}^{\prime}$ & Friction angle at failure \\
\hline$\varphi_{P T}^{\prime}$ & Friction angle at phase transformation \\
\hline
\end{tabular}

4. Vertical and horizontal actuators;

5. Load, pressure, and displacement transducers (Figure 1$)$.

This system is computer controlled with five control channels and up to sixteen data acquisition channels with 20-bit closed-loop controlled and data acquisition system. The main specifications of the hollow cylinder specimens are as follows: 150-mm triaxial cell with a 100-mm outside diameter, 60-

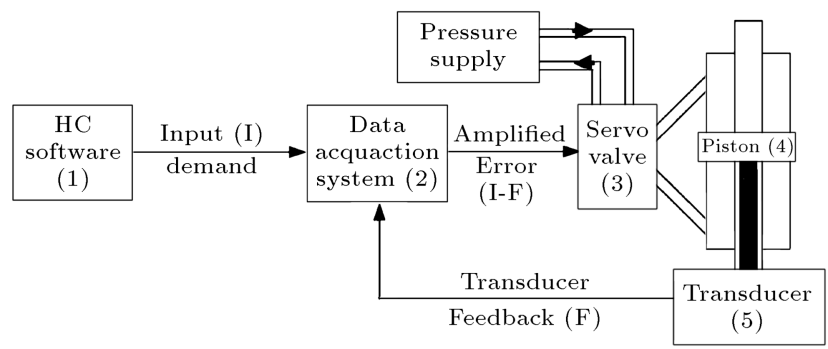

Figure 1. Closed-loop control system of hollow cylinder apparatus. 
mm inner diameter, and 200-mm height. The Axial actuator can apply an axial load of $+/-10 \mathrm{kN}$ with a stroke of $+/-25 \mathrm{~mm}$; the torsional actuator can apply a torsional force of $+/-200 \mathrm{Nm}$ with 90 degrees of rotation. The transducer resolutions for axial and rotational measurements include axial load $\leq 1 \mathrm{~N}$, axial displacement encoder $\leq 0.01 \mathrm{~mm}$, torque $\leq 0.01 \mathrm{Nm}$, and rotational encoder $\leq 1.5$ micron. These actuators are able to control up to a $5 \mathrm{~Hz}$ single axis. The inner cell, outer cell, and back pressures are applied through digitally controlled air valves in a closed loop with the inner and outer cells and back pressure transducers. This fully automated system allows applying frequencies up to $1 \mathrm{~Hz}$ simultaneously on 5-axis control, which is essential for applying magnitude and direction of the major and minor principal stresses. A compact self-contained unit provides all critical control, timing, and data acquisition functions for the test and the transducers.

\subsection{Tested materials and specimen preparation}

Two uniformly graded sands, Babolsar and Toyoura, which is a standard Japanese sand, were selected as test materials. Apart from the grading, the size and shape of the sand particles emerged as significant parameters that affect the response of sand in a remarkable manner. The selected materials are fine sand with relatively similar particle shapes. Babolsar sand has slightly coarser particles than Toyoura sand; thus, the effect of particle size could be investigated throughout the tests. The particles of Babolsar sand are sub-rounded to subangular as illustrated in Figure 2(a). Babolsar sand was obtained from the South coast of the Caspian Sea. Toyoura sand is uniform, fine material with mainly a sub-angular particles shape (Figure 2(b)). Particle size distribution curves of these two clean sands are shown in Figure 3. Index tests were performed based on ASTM standards [49-52]. Physical properties of soils used in the experimental program are summarized in Table 2. According to the USCS definition, these two sands can be characterized as poorly-graded sands (SP).

The HCA specimens were prepared by a wet tamping technique to minimize the degree of inherent anisotropy. In addition, the moist under compaction technique was used to obtain specimens with highly

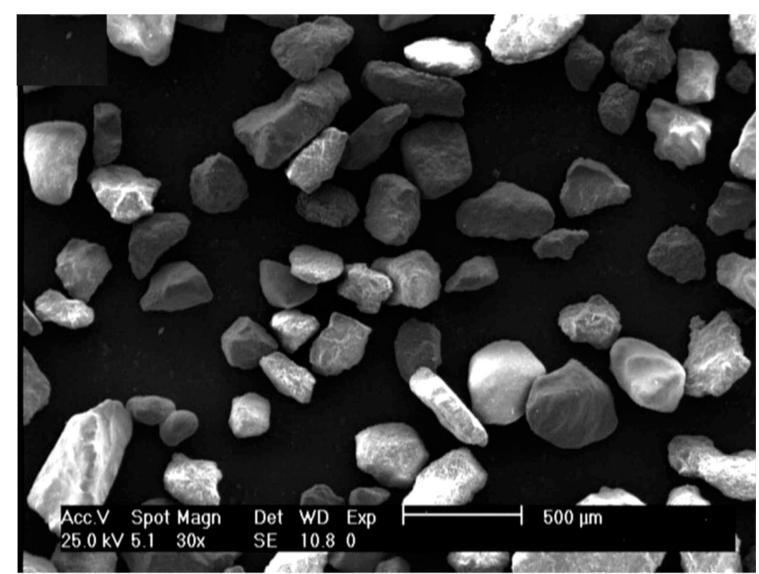

(a)

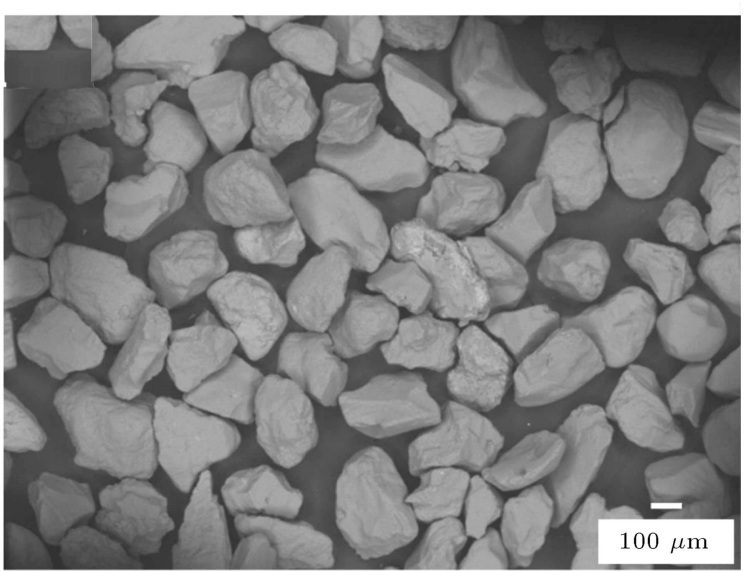

(b)

Figure 2. Particle images of (a) Babolsar sand and (b) Toyoura sands.

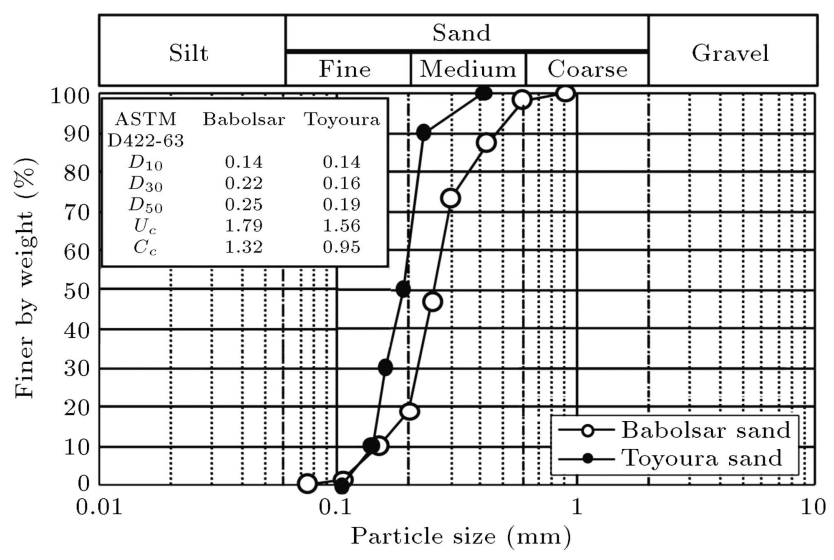

Figure 3. Gradation curves of tested soils.

Table 2. Physical properties of test materials.

\begin{tabular}{cccc}
\hline Soil type & Specific gravity & $\boldsymbol{e}_{\max }$ & $\boldsymbol{e}_{\min }$ \\
\hline Babolsar sand & 2.75 & 0.79 & 0.53 \\
Toyoura sand & 2.65 & 0.97 & 0.61 \\
Standard designation & ASTM D854-02 & ASTM D4254-00 & ASTM D4253-00 \\
\hline
\end{tabular}


uniform density over its height [53]. This technique has been applied extensively both in research and consulting practice [53,54]. The relative density of the dense specimens after consolidation and prior to shearing was about $75 \%(71 \%-79 \%)$.

For saturation, carbon dioxide was circulated through the specimen to displace air from the soil pores. Full saturation of the soil specimens was achieved by applying relatively low back pressures. After obtaining a minimum acceptable $B$-value (Skempton's parameter) of 0.96 , the consolidation procedure was initiated. The specimens were isotropically consolidated to a mean effective stress, $\sigma_{0 m}^{\prime}$, of $150 \mathrm{kPa}$. For more precise control of $\alpha$ and $b$, the internal and external cell pressures of dense specimens were kept constant and, therefore, $\alpha$ and $b$ were related by $b=\sin ^{2}(\alpha)$. The axial load, horizontal torque, and back pressure were all kept constant. Following consolidation, the specimens were subjected to the monotonic or cyclic loading. Two sets of tests were performed in this study: monotonic tests were conducted in a strain controlled manner by increasing deviator stress, $q$, until reaching failure (Figure 4(a)). Monotonic shear loading was applied to the dense specimens whose major principal stress inclination, $\alpha$, was fixed at $10^{\circ}, 30^{\circ}, 45^{\circ}, 60^{\circ}$, and $80^{\circ}$ (Figure $4(\mathrm{~b})$ ). The second type of tests was cyclic tests, in which the cyclic load was applied in a stress-controlled manner by a constant deviator stress ratio, $q / \sigma_{0 m}^{\prime}$ (Figure $4(\mathrm{a})$ ). Cyclic shear load was performed at fixed $\alpha$ (i.e. $\alpha=10^{\circ}, 30^{\circ}, 45^{\circ}, 60^{\circ}$, and $80^{\circ}$ ). Stress paths of these tests are shown in Figure 4(c). The typical effective stress path, $p^{\prime}-q$, curves of some monotonic and cyclic tests conducted on the dense specimens are shown in Figure 5. The mean normal effective stress is reduced to a critical value due to the undrained condition of loading (i.e., liquefaction in loose specimens and failure in the dense ones). The classic curves of $p^{\prime}-q$ show good agreement between the monotonic and cyclic tests at different stress paths.

Because loading frequency has little to no effect on the soil behavior in liquefaction testing $[55,56]$, all tests were performed at $0.2 \mathrm{~Hz}$ to ensure equilibration of pore water pressure throughout the specimen and, thus, provide more accurate pore pressure measurements. Twenty tests under a controlled state of principal stress direction, $\alpha$, and intermediate principal stress parameters, $b$, were conducted to investigate the effect of stress direction on the undrained behavior of sands. The tests' program and specimens' specifications are summarized in Table 3.

\subsection{Calculation of stresses and strains}

The average stresses and strains in thin-walled cylinders were determined through the following expressions $[45,7]$ :

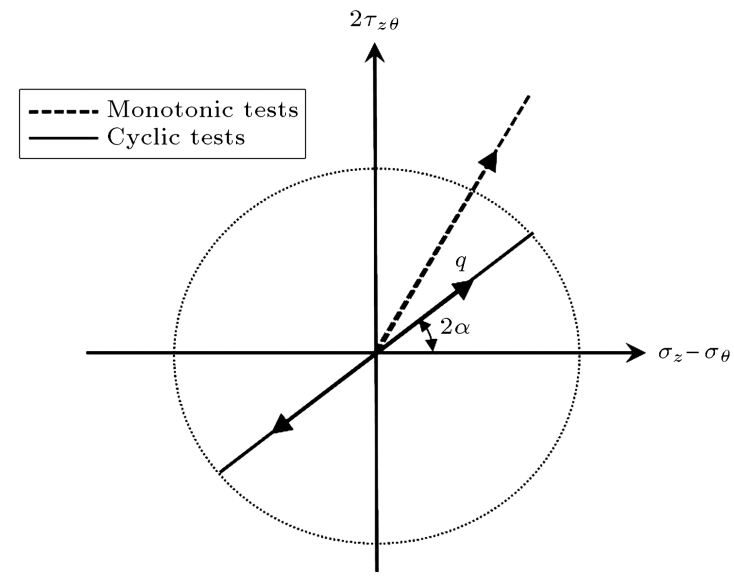

(a)

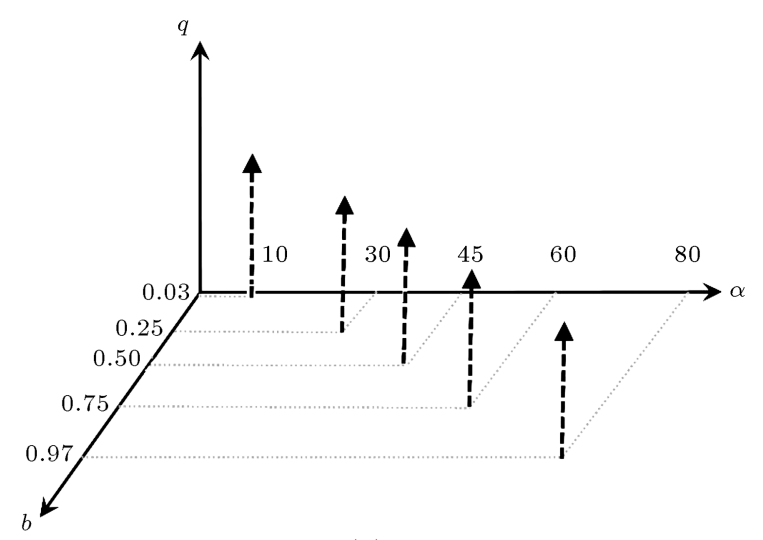

(b)

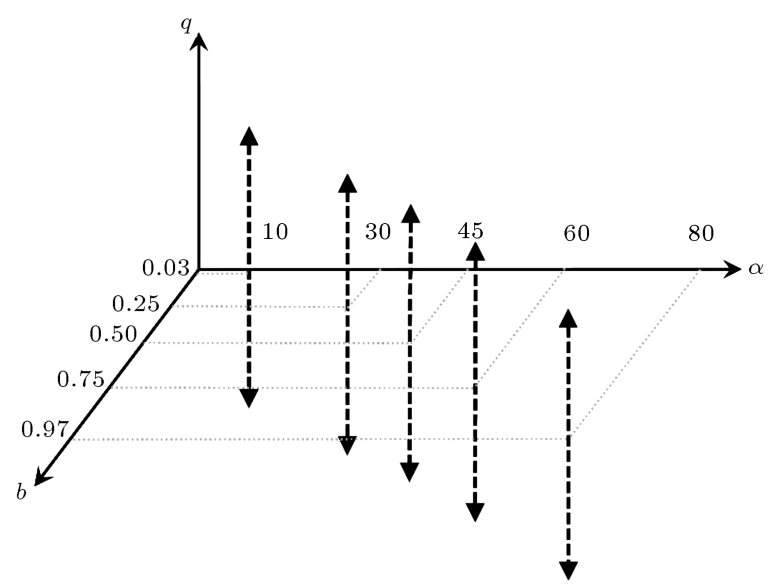

(c)

Figure 4. Stress paths for (a) monotonic and cyclic tests at $\tau_{z \theta}$ and $\left(\sigma_{z}-\sigma_{\theta}\right)$ space, (b) monotonic loading, and (c) cyclic loading.

Vertical stress:

$$
\sigma_{z}=\frac{F_{v}}{\pi\left(r_{o}^{2}-r_{i}^{2}\right)}+\frac{p_{o} r_{o}^{2}-p_{i} r_{i}^{2}}{r_{o}^{2}-r_{i}^{2}},
$$

in which $F_{v}$ is the vertical load, $p_{o}$ and $p_{i}$ are the outside and the inside pressures, and $r_{o}$ and $r_{i}$ are the 


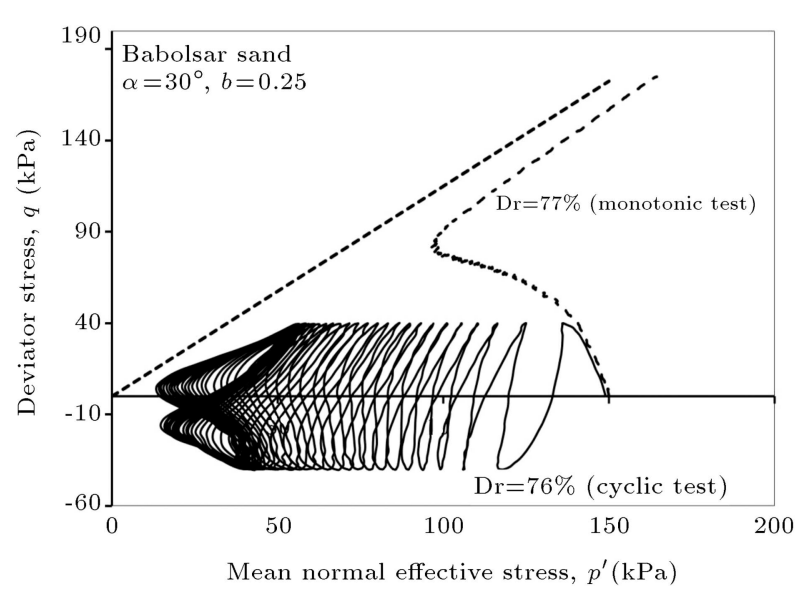

(a)

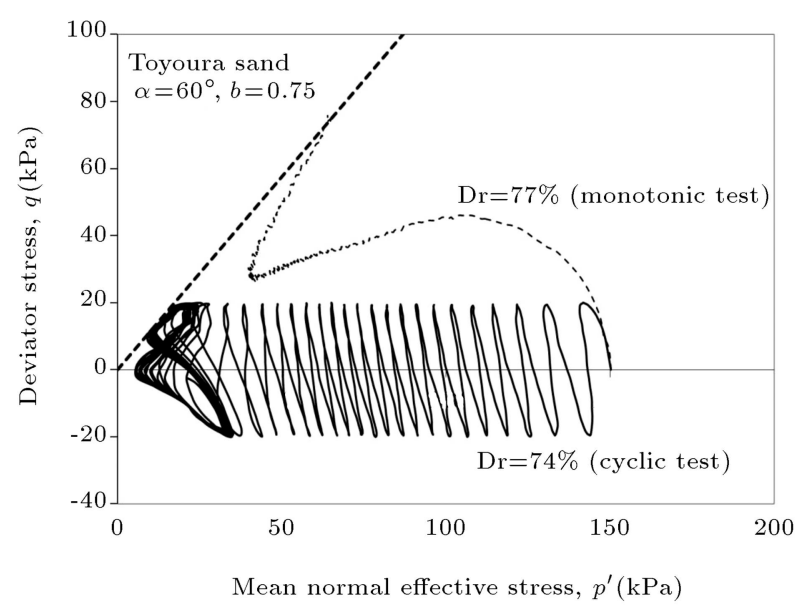

(b)

Figure 5. Example of effective stress paths for monotonic and cyclic tests: (a) Dense Babolsar and (b) dense Toyoura.

outside and the inside radii of the hollow cylinder.

\section{Radial stress:}

$$
\sigma_{r}=\frac{p_{o} r_{o}+p_{i} r_{i}}{r_{o}+r_{i}}
$$

Tangential stress:

$$
\sigma_{\theta}=\frac{p_{o} r_{o}-p_{i} r_{i}}{r_{o}-r_{i}}
$$

Shear stress:

$$
\tau_{z \theta}=\frac{3 T}{2 \pi\left(r_{o}^{3}-r_{i}^{3}\right)},
$$

in which $T$ is the torque applied to twist the hollow cylinder. Corrections were applied to the data after performing the tests due to vertical piston uplift, membrane strength, etc.

Vertical strain:

$$
\varepsilon_{z}=\frac{\Delta H}{H_{0}},
$$

in which $H_{0}$ is the initial height of specimens, and $\Delta H$ is the change in the height of the hollow cylinder specimen.

Radial strain:

$$
\varepsilon_{r}=-\frac{l_{o}-l_{i}}{r_{o}-r_{i}} .
$$

Tangential strain:

$$
\varepsilon_{\theta}=-\frac{l_{o}+l_{i}}{r_{o}+r_{i}},
$$

in which $l_{o}$ and $l_{i}$ are the changes in the outside and inside radii determined through the following expressions:

$$
\begin{aligned}
& l_{o}=\sqrt{\frac{\pi\left(H_{0} r_{o}^{2}\right)+\Delta I_{v o l}+\Delta V}{\pi h}}-r_{o}, \\
& l_{i}=\sqrt{\frac{\pi\left(H_{0} r_{i}^{2}\right)+\Delta I_{v o l}}{\pi h}}-r_{i},
\end{aligned}
$$

in which $\Delta I_{v o l}$ and $\Delta V$ are the changes in the volumes of the inner cell and the specimen, respectively.

Shear strain:

$$
\varepsilon_{z \theta}=\frac{\Delta \theta\left(r_{o}^{3}-r_{i}^{3}\right)}{3 H\left(r_{o}^{2}-r_{i}^{2}\right)},
$$

in which:

$$
\Delta \theta=\frac{\Delta H_{L V D T}}{r_{\text {measurement plate }}},
$$

where $\Delta H_{L V D T}$ is the recorded change in the horizontal LVDT reading, and $r_{\text {measurement plate }}$ is the distance from the center to the radio wire cord of the pie-shaped measurement plate.

Major principal stress direction to the vertical axis, $\alpha$, is as follows:

$$
\alpha=\frac{1}{2} \tan ^{-1}\left(\frac{\tau_{z \theta}}{\sigma_{z}-\sigma_{\theta}}\right) .
$$

Major principal strain increment direction to the vertical axis, $\alpha_{d \varepsilon}$, is:

$$
\alpha_{d \varepsilon}=\frac{1}{2} \tan ^{-1}\left(\frac{d \gamma_{z} \theta}{d \varepsilon_{z}-d \varepsilon_{\theta}}\right) .
$$

Non-coaxiality between the principal stress and strain increment directions, $\zeta$, is:

$$
\zeta=\alpha_{d \varepsilon}-\alpha
$$


Table 3. Characterization of the specimens and their loading condition.

\begin{tabular}{|c|c|c|c|c|c|}
\hline No. & Sand type & $\begin{array}{c}\text { Loading } \\
\text { condition }\end{array}$ & $\alpha$ (degree) & Dr (\%) & $e$ \\
\hline 1 & \multirow{10}{*}{ Babolsar } & \multirow{5}{*}{ Cyclic } & 10 & 73 & 0.60 \\
\hline 2 & & & 30 & 76 & 0.59 \\
\hline 3 & & & 45 & 77 & 0.59 \\
\hline 4 & & & 60 & 74 & 0.60 \\
\hline 5 & & & 80 & 76 & 0.593 \\
\hline 6 & & \multirow{5}{*}{ Monotonic } & 10 & 75 & 0.60 \\
\hline 7 & & & 30 & 77 & 0.59 \\
\hline 8 & & & 45 & 73 & 0.60 \\
\hline 9 & & & 60 & 73 & 0.60 \\
\hline 10 & & & 80 & 77 & 0.59 \\
\hline 11 & \multirow{10}{*}{ Toyoura } & \multirow{5}{*}{ Cyclic } & 10 & 74 & 0.70 \\
\hline 12 & & & 30 & 71 & 0.72 \\
\hline 13 & & & 45 & 78 & 0.69 \\
\hline 14 & & & 60 & 74 & 0.70 \\
\hline 15 & & & 80 & 75 & 0.70 \\
\hline 16 & & \multirow{5}{*}{ Monotonic } & 10 & 78 & 0.69 \\
\hline 17 & & & 30 & 76 & 0.70 \\
\hline 18 & & & 45 & 76 & 0.70 \\
\hline 19 & & & 60 & 77 & 0.69 \\
\hline 20 & & & 80 & 74 & 0.70 \\
\hline
\end{tabular}

\section{Test results and discussion}

\subsection{Effect of stress direction on internal friction angle at steady state}

The shear strength of granular material generally results from internal friction. Many researchers have investigated the parameters that affect the internal friction angle [57-64]. Sadrekarimi and Olson conducted a comprehensive review of the factors affecting the internal friction angle [63]. They reported that internal friction originates from interparticle sliding friction and the geometrical interface. The friction mobilized by the sliding of two adjacent particles is referred to as interparticle sliding friction $\left(\varphi_{\mu}^{\prime}\right)$ and is mainly affected by particle surface roughness [57]. Confining stress has no significant effect on interparticle sliding friction. Geometrical interface friction $\left(\varphi_{g}^{\prime}\right)$ is affected by the geometrical characteristics of the particles and their movement mechanisms. Geometrical interface resistance can be divided into two major parts:

(a) Resistance mobilized by the interface of particles, which arises from particles pushing against, climbing over, and damaging adjacent particles $\left(\varphi_{d}^{\prime}\right)$;

(b) Resistance mobilized by particle rearrangement and damage $\left(\varphi_{p}^{\prime}\right)[57]$. The geometrical interface angle $\left(\varphi_{d}^{\prime}\right)$ range increases from $0^{\circ}$ (at high effective confining pressures) to $30^{\circ}$ (at low effective confining pressures) and depends on the initial density, effective confining stress, and surface roughness of the particles [60-62].

The mobilized friction angle $\left(\varphi_{m o b}^{\prime}\right)$ can be written as follows:

$$
\varphi_{m o b}^{\prime}=\varphi_{\mu}^{\prime}+\varphi_{g}^{\prime}=\varphi_{\mu}^{\prime}+\varphi_{d}^{\prime}+\varphi_{p}^{\prime} .
$$

Determination of the steady-state friction angle for the dense sand contains uncertainties. Moreover, the effects of loading mode and particle crushing (at high effective stress) on the steady-state line are questionable. In addition to the above uncertainties, the determination of the steady-state condition is somewhat difficult. In this study, the failure condition is presumed to be a steady-state condition, although it may not be exactly so. The failure of dense sand is defined here as the first occurrence of either $6 \%$ Double Amplitude (DA) or 6\% Single Amplitude (SA) shear strain. The stress paths of deviator stress and mean normal effective stress of Babolsar and Toyoura sands are shown in Figure 6. The monotonic tests were applied for locating the failure line more accurately. As illustrated in this figure, changes of $\alpha$ have no significant effect on the internal friction angle at steady state $\left(\varphi_{s s}\right)$ or phase transformation $\left(\varphi_{P T}\right)$ in dense Babolsar and Toyoura sands. Many studies have reported that the direction and rotation of the principal stress greatly influenced the internal friction angle at steady state [65-68]. However, Towhata and Ishihara [69] and Arthur et al. [2] reported that the 

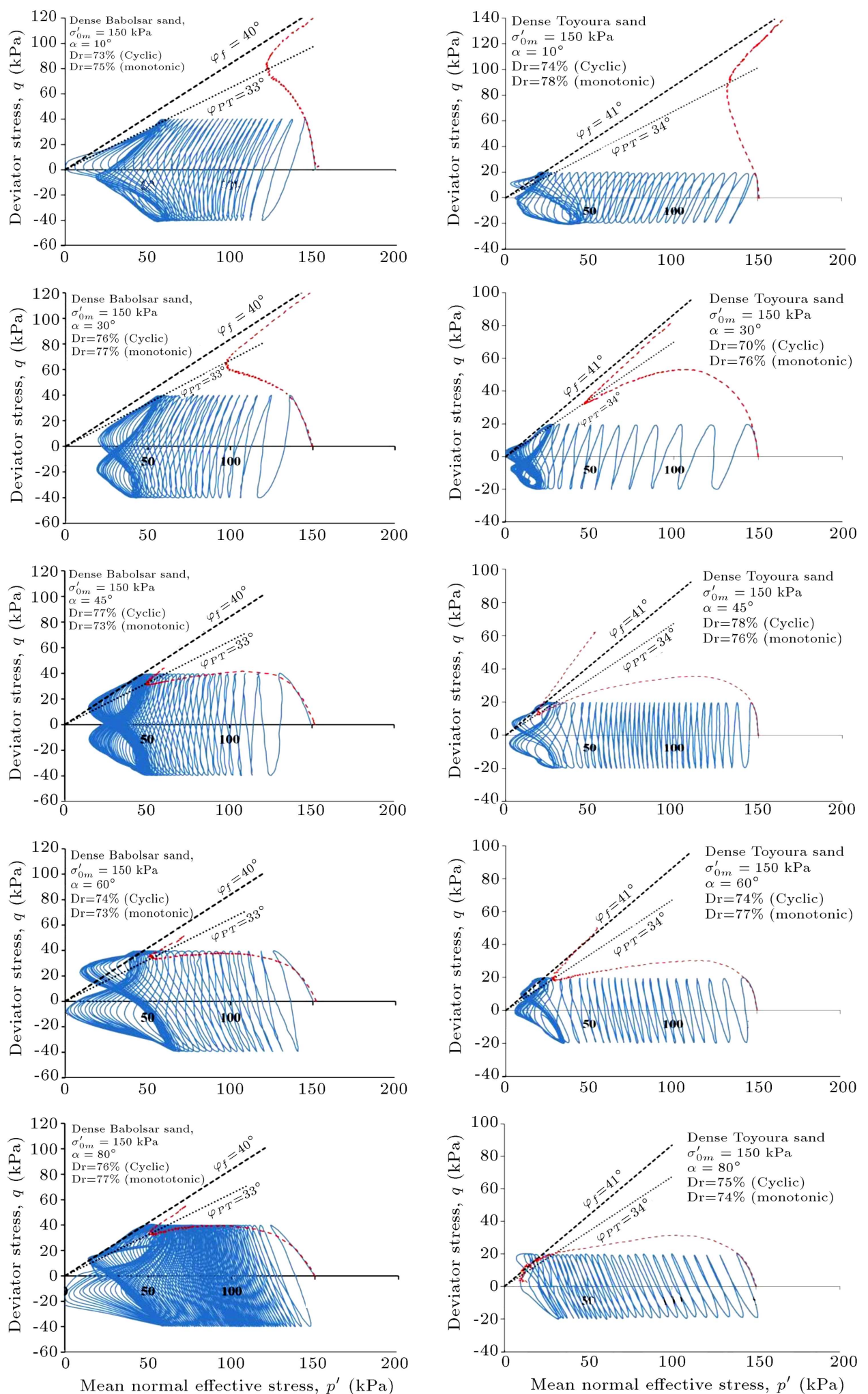

Figure 6. Stress paths of deviator stress with mean normal effective stress in Babolsar and Toyoura sands.

angle of shearing resistance was not affected by the anisotropy induced by the principal stress direction. In the current study, the effect of stress anisotropy on the internal friction angle was investigated at high levels of strain. The results were in agreement with the observations of Towhata and Ishihara [69] and Arthur et al. [2]. It should be noted that the uniqueness of the steady state at a given void ratio is vague. Some test results support the idea of a unique steady state, while others indicate that the strain rate, the deformation 
mode, the loading path (compression or extension), and the deposition mode might affect the steady-state line [70]. The dense condition of specimens caused the contribution of rearrangement $\left(\varphi_{p}^{\prime}\right)$ to decrease and geometrical interference to be dominated by dilation $\left(\varphi_{d}^{\prime}\right)$. In addition, $\varphi_{d}^{\prime}$ tends to become zero at the steady state. Conversely, restriction of particles against rearrangement (as a result of the dense condition of specimens) reduced the effect of loading direction on the geometrical interference at failure. The degree of anisotropy is generally associated with the initial fabric of the sand. An increase in strain will destroy particle interlock and initial fabric. This will decrease the degree of anisotropy as the strain increases, and the sand behavior will become isotropic. Thus, the effect of stress anisotropy on the internal friction angle will decrease due to the destruction of the soil fabric.

The results revealed that for a particular void ratio, confining stress, and laboratory procedure, the friction angle at steady state remained unchanged in dense sand and was not affected by the stress direction (Figure 6).

\subsection{Effect of stress direction on non-coaxiality}

Non-coaxiality can be defined as the non-coincidence of the principal stress axis and the principal strain rate axis. Conventional elastoplasticity theory states that, for isotropic materials subjected to proportional loading, the principal directions of strain increment should always be the same as those of the principal stress tensor. However, strong experimental and micromechanics-based pieces of evidence suggest that the coaxiality cannot be satisfied in granular materials [71].

Figures 7 and 8 show the direction of major principal stress and major principal strain increments for dense Babolsar and Toyoura sands. Variations of major principal stress/strain increment directions are plotted with $N / N_{f}$ in cyclic tests and $\gamma_{o c t}$ in monotonic ones, where $N$ is the number of cycles, $N_{f}$ is the number of cycles to the failure of specimens, and $\gamma_{o c t}$ is the octahedral shear strain.

In both monotonic and cyclic tests, the major strain increment directions for $\alpha=10^{\circ}$ and $30^{\circ}$ are slightly higher than the stress directions. For $\alpha=45^{\circ}$, $60^{\circ}$, and $90^{\circ}$, the major principal strain increment directions are slightly lower than the major principal stress directions due to the cross anisotropic nature of the specimen (i.e., the bedding planes are horizontal). At $\alpha=10^{\circ}$ and $30^{\circ}$, the horizontal bedding planes will make the strain increment direction become more horizontal and, consequently, slightly higher $\alpha_{d \varepsilon}$ than $\alpha$. At $\alpha=45^{\circ}$, in which the plane of maximum shear stress is aligned to the horizontal plane, this also occurs, yet to a lesser extent. However, at $\alpha=60^{\circ}$ and $80^{\circ}$, the strain increment direction moves over

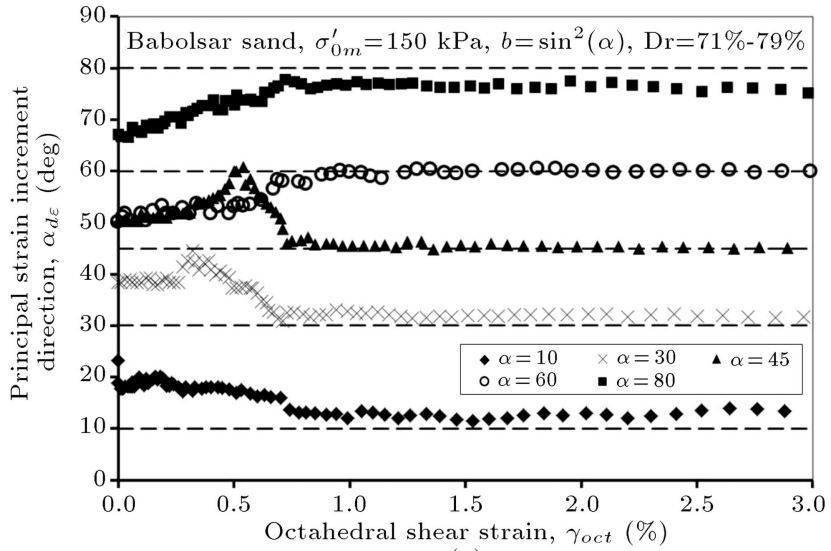

(a)

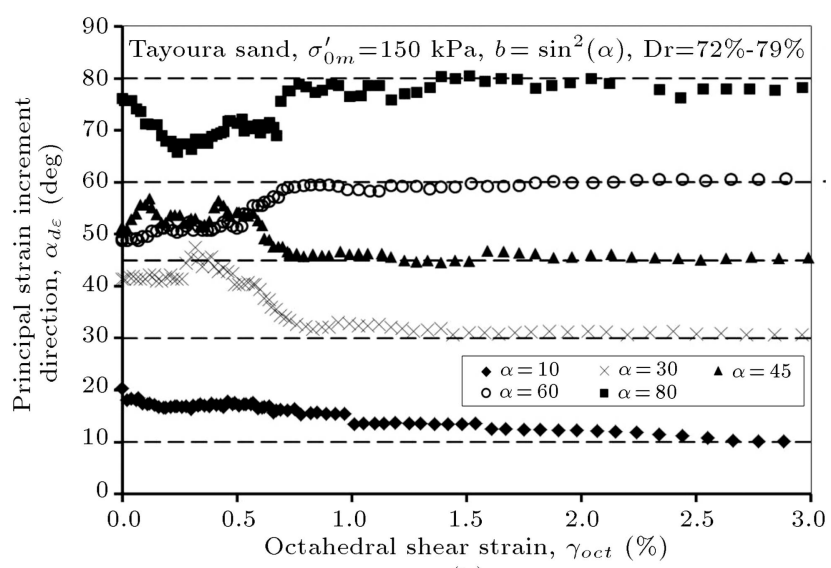

(b)

Figure 7. Directions of principal strain increments versus shear strain for monotonic torsional shear tests of (a) Babolsar sand and (b) Toyoura sand.

to the other side of the principal stress direction. These results are in good agreement with those of the laboratory tests reported by Miura et al. [66] and Cai et al. [72].

As shown in Figures 7 and 8, the initial response resulting from fabric anisotropy creates an initial deviation of major strain increment direction from the major stress direction. By increasing the shear strains, the major strain increment direction aligns with the major stress direction, and the non-coaxiality value decreases. This is owing to the diverse role of elastic and plastic parts of the strain. Elastic component of strain is considerable at the early stages of loading and causes higher values of non-coaxiality. In higher shear strains, the contribution of elastic strains decreases and the plastic strains will be dominant; consequently, the non-coaxiality decreases. For cyclic tests, the initial response is highlighted for the first 7 or 8 cycles. In the monotonic tests, the effects of initial anisotropy drastically reduce after $0.5 \%$ to $1 \%$ octahedral shear strain. The outstanding fact is that the peak shear strength of these specimens occurs at $0.5 \%-1 \%$ shear strain. In other words, the effect of initial anisotropy on the sand response is mainly detected before the peak 


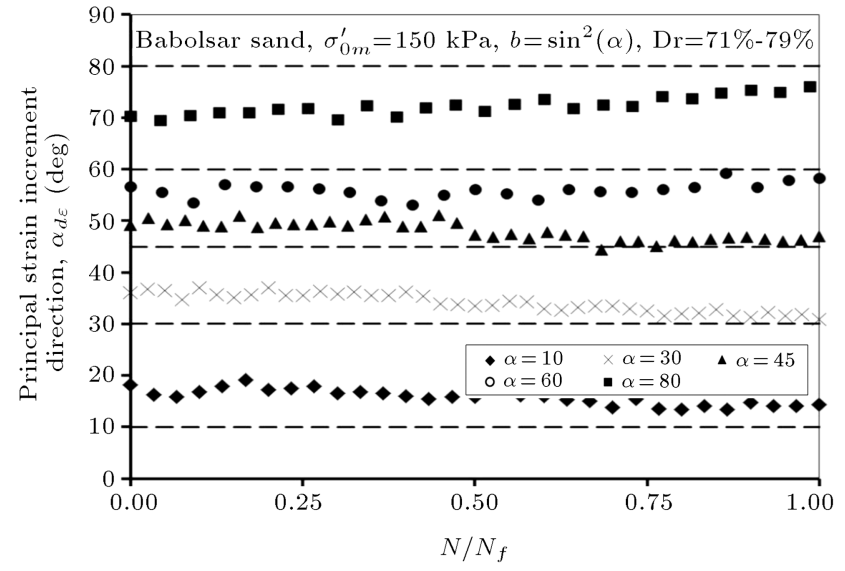

(a)

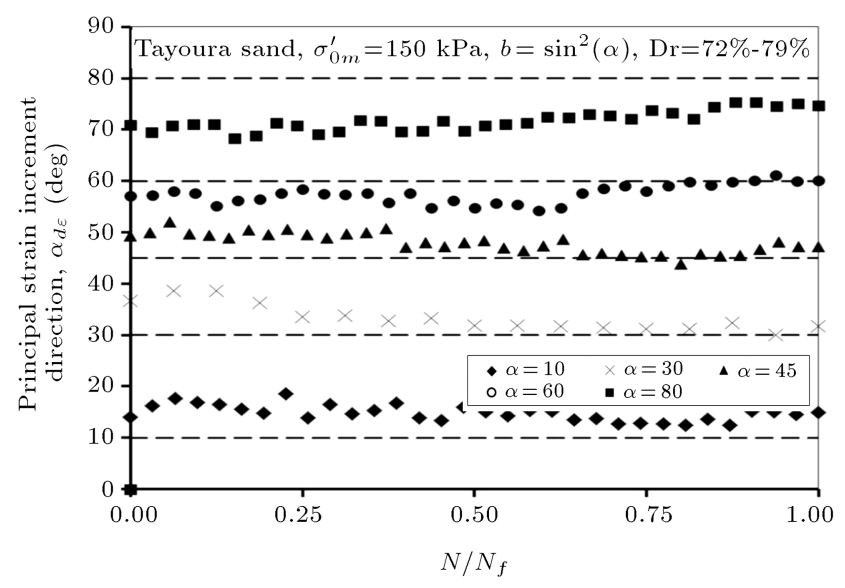

(b)

Figure 8. Directions of principal strain increments versus cycle ratio for cyclic torsional shear tests of (a) Babolsar sand and (b) Toyoura sand.

shear strength. When specimens approach failure, the sand behaves as an isotropic material. Cai et al. [72] and Rodriguez and Lade [10] observed similar initial responses and higher values of non-coaxiality before the peak shear strength.

In addition to the initial anisotropy, the stress anisotropy has significant effect on the value of noncoaxiality. For the tests with $\alpha=45^{\circ}$, where the specimens are subjected to torsional loading, the noncoaxiality is minimum (i.e., less than $6^{\circ}$ ). In this test condition, the major principal stress is oriented such that the horizontal bedding plane (i.e., the weakest plane) direction is close to the direction of the maximum shear stress ratio, $q / \sigma_{0 m}^{\prime}$. The largest deviations between $\alpha$ and $\alpha_{d \varepsilon}$ occurred in the tests with $\alpha=10^{\circ}$ and $\alpha=80^{\circ}$, where the specimens were subjected to compression and extension loading, respectively. In these loading conditions, the non-coaxiality increased more than $10^{\circ}$ for both Babolsar and Toyoura sands. For a specific value of $\alpha$, the non-coaxiality values of Babolsar sand were slightly higher (i.e., these were about $1^{\circ}-2^{\circ}$ ) than those of the Toyoura sand. Apart from grain size, the morphological characteristics of these two types of sand particles are relatively similar. The behavior could, thus, be associated with the coarser particles of Babolsar sand.

\subsection{Effect of stress direction on the pore water pressure}

Excess pore water pressure during cyclic loading has two components. The first is the transient excess pore water pressure, $u_{t}$, which denotes the change in applied mean normal stress for the saturated sand. Because the variation in the transient excess pore water pressure is associated with total mean normal stress, it has little influence on soil effective stress. The second component is residual excess pore water pressure, $u_{r}$, which increases with the progressive plastic deformation of the soil skeleton. The residual excess pore water pressure is thus directly related to the shear strength and stiffness of soil [56].

The residual excess pore water pressure in one cycle of a stress-controlled test equals the excess pore water pressure at zero deviator stress. The pore water pressure is generally normalized by the initial effective stress, known as the excess pore water pressure ratio (i.e., $r_{u r}=u_{r} / \sigma_{0 m}^{\prime}$ and $r_{u t}=u_{t} / \sigma_{0 m}^{\prime}$ ) [56].

Figure 9 shows the transient excess pore water pressures of Babolsar and Toyoura specimens tested at different principal stress directions. As can be observed from this figure, the value of transient excess pore water pressure for $\alpha=10^{\circ}$ and $\alpha=80^{\circ}$ tests is slightly greater than those of the tests carried out at $\alpha=45^{\circ}$. The transient excess pore water pressure resulted from the increase and decrease of loads in cycles. Stiffer soil skeleton resulted in higher transient pore water pressure. At the same time, lower shear strains led to lower residual pore water pressure. The residual excess pore water pressure generated in the cyclic tests of Babolsar and Toyoura sands is indicated in Figure 10. For both Babolsar and Toyoura sands, more residual excess pore pressure was observed when the principal stress directions were inclined at $30^{\circ}, 45^{\circ}$, and $60^{\circ}$ in which the specimens showed lower cyclic resistance. Lower cyclic shear resistance led to the development of higher plastic strain, as well as residual excess pore water pressure. These results were in good agreement with those of HCA tests performed by Logeswaran [73] and Vipulanantham [74]. They observed that the lowest cyclic resistance (i.e., minimum soil stiffness) occurred when $\alpha$ was around $30^{\circ}$ to $60^{\circ}$ (i.e., the minimum value was observed at $\alpha=45^{\circ}$ ), in which the plane of maximum shear stresses was inclined to the bedding plane.

It was observed that, for the given initial fabric and confining pressure, the transient and residual excess pore water pressures were influenced by the direction of the major principal stress. Furthermore, 


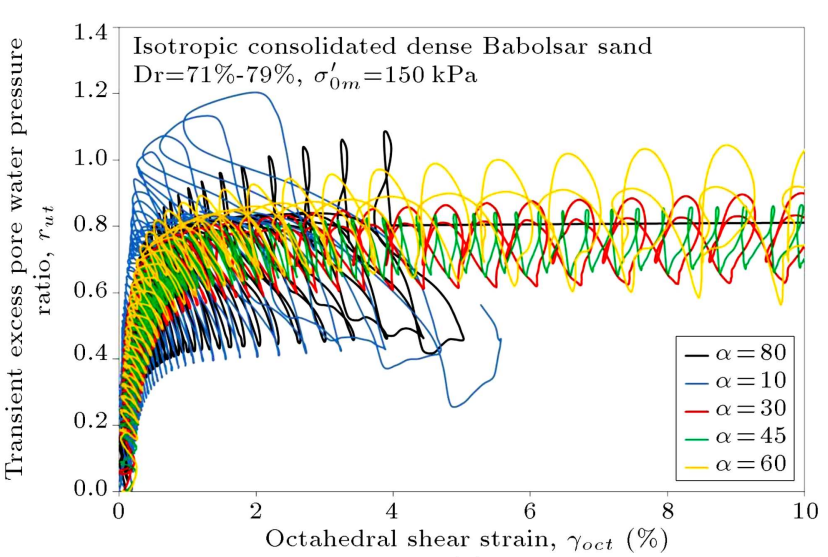

(a)

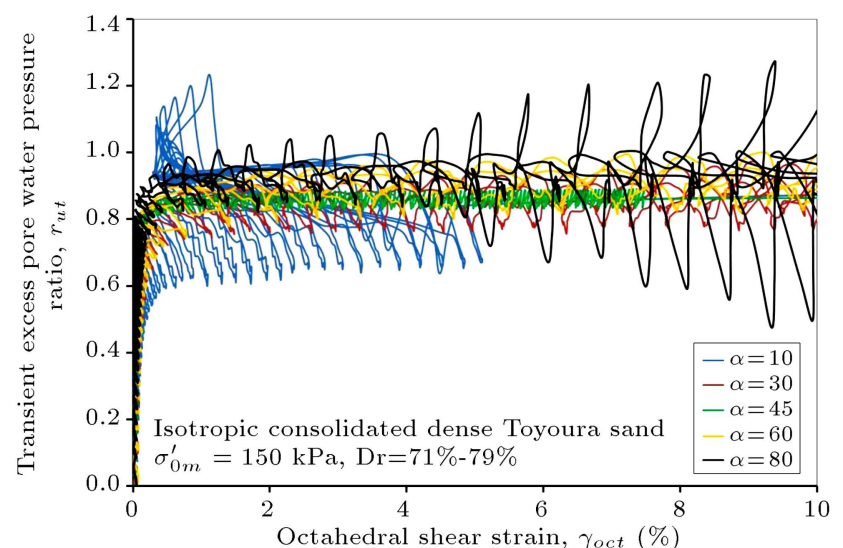

(b)

Figure 9. Transient excess pore water pressure generated in cyclic tests of (a) dense Babolsar sand and (b) dense Toyoura sand.

these effects could be amplified by the size of the particles. The effect of major principal stress on the residual excess pore water pressure generation was more noticeable in Babolsar sand. Finer particles size, more uniformity, and more roundness of Touyora sand particles decrease the degree of fabric anisotropy and, thus, the direction of the major principal stress has little effect on its residual excess pore water pressure generation.

\section{Conclusion}

In order to investigate the effect of stress inclination on the monotonic and cyclic behavior of dense sands, a series of undrained torsional shear tests were carried out on hollow cylinder specimens. Twenty monotonic and cyclic tests were conducted on dense Toyoura and Babolsar sands. The tests were performed in a controlled condition of the major principal stress direction, $\alpha$, initial confining stress, $\sigma_{0 m}^{\prime}$, and initial relative density, Dr. According to the results of the experiments, some of the main findings are presented as follows:

1. The direction of major principal stress, $\alpha$, had

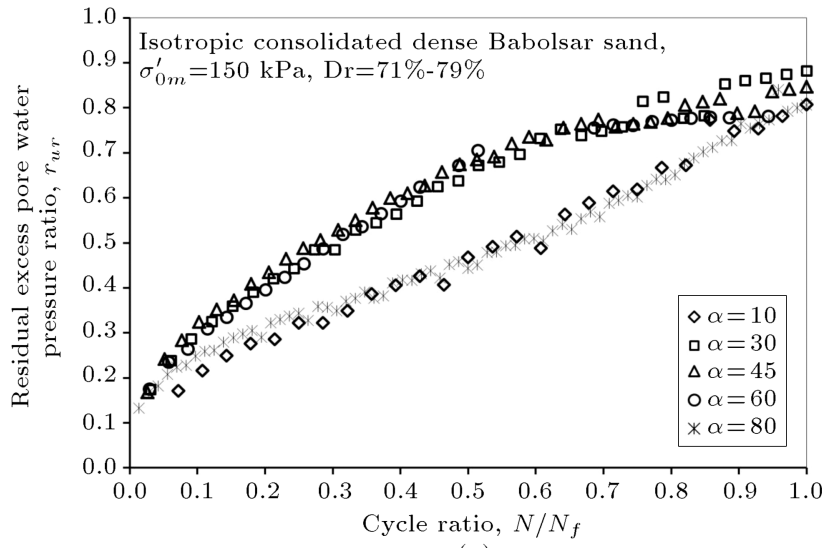

(a)

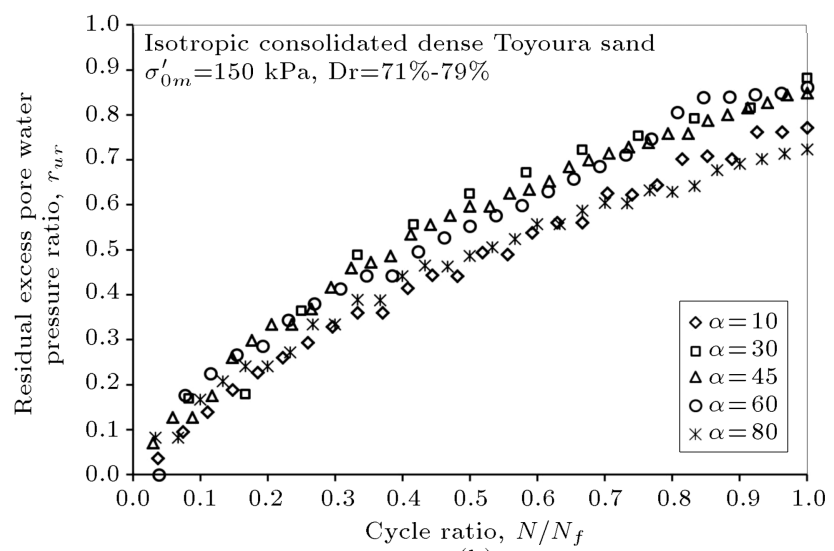

(b)

Figure 10. Residual excess pore water pressure generated in cyclic tests of (a) dense Babolsar sand and (b) dense Toyoura sand.

no significant effect on the internal friction angle at failure $\left(\varphi_{f}\right)$ or phase transformation $\left(\varphi_{P T}\right)$ in both Babolsar and Toyoura sands (Figure 6). The dense condition of the specimens caused the contribution of rearrangement $\left(\varphi_{p}^{\prime}\right)$ to decrease and the geometrical interference to be dominated by dilation $\left(\varphi_{d}^{\prime}\right)$, whereas the dilation angle tended to fall to zero at failure. Moreover, sand anisotropy is mainly affected by the initial fabric. An increase in strain destroyed the particle interlock and the initial fabric. Thus, the degree of anisotropy decreased with an increase in strain, and the sand behavior became more isotropic. At high levels of strain, the stress anisotropy had a minimum effect on the soil internal friction angle;

2. Although the specimen preparation method employed in this study (i.e., wet tamping technique) reduced the fabric anisotropy, still, the cross anisotropy resulting from the bedding plane caused the strain increment direction to be greater than the direction of the major principal stress for specimens tested at $\alpha<45^{\circ}$. As can be seen in Figure 8, the plane of cross anisotropy had reverse effect on the specimens tested at $\alpha=45^{\circ}, 60^{\circ}$, and $80^{\circ}$, while the 
major principal stress direction was greater than the strain increment direction;

3. The maximum non-coaxiality between the directions of the principal stress and principal strain increments occurred around the peak shear strength (i.e., $\gamma_{\text {oct }}=0.5 \%-1 \%$ ), when the main particles interlock began to be destroyed;

4. Babolsar and Toyoura sand particles had relatively similar morphological characteristics; however, Babolsar sand had coarser particles that increased the degree of anisotropy. For a specific value of $\alpha$, the non-coaxiality of Babolsar sand was slightly greater $\left(1^{\circ}-2^{\circ}\right)$ than that of Toyoura sand;

5. For specimens tested at $\alpha=30^{\circ}, 45^{\circ}$, and $60^{\circ}$, the direction of maximum shear stress was aligned with the weakest plane (i.e., horizontal plane); therefore, the specimens showed softer responses to the loading. It resulted in higher residual excess pore water pressure and lower transient excess pore water pressure;

6. Apart from the morphological characteristics of the sand particles, particle size may have been influenced by the soil anisotropic behavior. The results showed that the major principal stress direction had greater influence on the response of Babolsar specimens to monotonic and cyclic loading. This may be related to the coarser particles in this type of sand.

\section{References}

1. Roscoe, K.H., Bassett, R.H., and Cole, E.R. "Principal axes observed during simple shear of a sand", Proceedings of the Geotech Conference, Oslo, 1, pp. 231-237 (1967).

2. Arthur, J.R.F., Chua, K.S., and Dunstan, T. "Induced anisotropy in a sand", Geotechnique, 27, pp. 13-30 (1977). http://dx.doi.org/10.1680/geot.1985.35.4.471

3. Yu, H.S., Plasticity and Geotechnics, Springer (2006).

4. Airey, D.W., Budhu, M., and Wood, D.M. "Some aspects of the behaviour of soils in simple shear", In Development in Soil Mechanics and Foundation Engineering, P.K. Banerjee and R. Butterfield, Eds., Elsevier, 2, pp. 185-213 (1985).

5. Saada, A.S. and Baah, A.K. "Deformation and failure of a cross anisotropic clay under combined stresses", Proc. 3rd Pan Am. Conf. Soil Mech., Caracas, 1, pp. 67-88 (1967).

6. Lade, P.V. "Torsion shear tests on cohesionless soil", Proc. 5th Pan Am. Conf. Soil Mech., Buenos Aires, 1, pp. 117-127 (1975).

7. Hight, D.W., Gens, A., and Symes, M.J. "The development of a new hollow cylinder apparatus for investigating the effects of principal rotation in
Soils", Geotechnique, 33(4), pp. 355-383 (1983). http://dx.doi.org/10.1680/geot.1983.33.4.355

8. Lade, P.V., Nam, J., and Hong, W.P. "Shear banding and cross-anisotropic behavior observed in laboratory sand tests with stress rotation", Can. Geotech. J., 45(1), pp. 74-84 (2008). http://dx.doi.org/10.1139/T07-078

9. Lade, P.V., Nam, J., and Hong, W.P. "Interpretation of strains in torsion shear tests", Computers and Geotechnics, 36, pp. 211-225 (2009). https://doi.org/10.1016/j.compgeo.2008.02.001

10. Rodriguez, N.M. and Lade, P.V. "Effects of principal stress directions and mean normal stress on failure criterion for cross-anisotropic sand", Journal of Engineering Mechanics, 139(11), pp. 1592-1601 (2013). DOI: $10.1061 /($ ASCE)EM.1943-7889.0000595

11. Arthur, J.R.F. and Menzies, B.K. "Inherent anisotropy in a sand", Géotechnique, 22(1), pp. 115-128 (1972).

12. Oda, M. "Initial fabric and their relations to mechanical properties of granular material", Soils and Foundations, 12(1), pp. 17-36 (1972).

13. Matsuoka, H. "A microscopic study on shear mechanism of granular materials", Soils and Foundations, 14(1), pp. 29-43 (1974).

14. Nemat-Nasser, S. "A micromechanically-based constitutive model for frictional deformation of granular materials", Journal of the Mechanics and Physics of Solids, 48(6-7), pp. 1541-1563 (2000).

15. Matsuoka, H. and Geka, H. "A stress-strain model for granular materials considering mechanism of fabric change", Soils and Foundations, 23(2), pp. 83-97 (1983).

16. Rothenburg, L. and Bathurst, R.J. "Analytical study of induced anisotropy in idealized granular materials", Géotechnique, 39(4), pp. 601-614 (1989).

17. Oda, M. "Inherent and induced anisotropy in plasticity theory of granular soils", Mechanics of Materials, 16(1-2), pp. 35-45 (1993).

18. Li, X.S. and Dafalias, Y.F. "Constitutive modeling of inherently anisotropic sand behaviour", Journal of Geotechnical and Geoenvironmental Engineering, 128(10), pp. 868-880 (2002).

19. Guo, P.J. and Stolle, D.F. "On the failure of granular materials with fabric effects", Soils and Foundations, 45(4), pp. 1-12 (2005).

20. Radjai, F. and Azéma, E. "Shear strength of granular materials", European Journal of Environmental and Civil Engineering, 13(2), pp. 203-218 (2009).

21. Wrzesiński, G. and Lechowicz, Z. "Influence of the rotation of principal stress directions on undrained 
shear strength", Annals of Warsaw University of Life Sciences-SGGW, Land Reclamation, 45(2), pp. 183192 (2013).

22. Al-Rkaby, A.H., Chegenizadeh, A., and Nikraz, H.R. "Directional-dependence in the mechanical characteristics of sand: a review", International Journal of Geotechnical Engineering, 10(5), pp. 499-509 (2016).

23. Casagrande, A. and Carillo, N. "Shear failure of anisotropic materials", J. Boston Soc. Civil Eng., 31(4), pp. 122-135 (1944).

24. Parkin, A.K., Gerrard, C.M., and Willougby, D.R. "Discussion on deformation of sand in shear", Journal of Soil Mechanics and Foundation Division, 94(1), pp. 336-340 (1968).

25. Arthur, J.R.F. and Assadi, A. "Ruptured sand sheared in plane strain", Proceeding 9th International Conference on Soil Mechanics and Foundation Engineering, Tokyo, pp. 19-22 (1977).

26. Li, X. and Yu, H.S. "Influence of loading direction on the behaviour of anisotropic granular materials", International Journal of Engineering Science, 47, pp. 1284-1296 (2009).

27. Yang, L.T., Li, X., Yu, H.S., and Wanatowski, D. "A laboratory study of anisotropic geomaterials incorporating recent micromechanical understanding", Acta Geotechnica, 11(5), pp. 1-19 (2015a).

28. Yang, Y., Fei, W., Yu, H.S., Ooi, J., and Rotter, M. "Experimental study of anisotropy and non-coaxiality of granular solids", Granular Matter., 17(2), pp. 189196 (2015b).

29. Symes, M.J., Gens, A., and Hight, D.W. "Undrained anisotropy and principal stress rotation in saturated sand", Geotechnique, 34(1), pp. 11-27 (1984).

30. Wong, R.K.S. and Arthur, J.F.R. "Induced and inherent anisotropy in sand", Géotechnique, 35(4), pp. 471-481 (1985).

31. Chan, F.W.K. and Brown, S.F. "Significance of principal stress rotation in pavements", Proceedings of the 13 th International Conference on Soil Mechanics and Foundation Engineering, New Delhi, India, pp. 18231826 (1994).

32. Towhata, I., Kawasaki, Y., Harada, N., and Sunaga, M. "Contraction of soil subjected to traffic-type stress application", Proceedings of the International Symposium on Pre-Failure Deformation Characteristics of Geomaterials, Sapporo, Japan, pp. 305-310 (1994).

33. Yang, Z.X., Li, X.S., and Yang, J. "Undrained anisotropy and rotational shear in granular soil", Geotechnique, 57(4), pp. 371-384 (2007).

34. Lade, P.V. and Duncan, J.M. "Cubical triaxial tests on cohesionless soil", Journal of the Soil Mechanics and Foundation Division, ASCE, 99(SM10), pp. 793-811 (1973).

35. Ochiai, H. and Lade, P.V. "Three-dimensional behavior of sand with anisotropic fabric", J. Geotech. Eng., 109(10), pp. 1313-1328 (1983).
36. Tatsuoka, F. "Stress-strain behavior of an idealized anisotropic granular material", Soils and Foundations, 20(3), pp. 75-90 (1980).

37. Shibuya, S. "Undrained behaviour of granular materials under principal stress rotation", $\mathrm{PhD}$. Thesis, Imperial College of Science, Technology and Medicine, University of London (1985).

38. Shibuya, S. and Hight, D.W. "On the stress path in simple shear", Geotechnique, 37(4), pp. 511-515 (1987).

39. Shibuya, S., Hight, D.W., and Jardine, R.J. "Fourdimensional local boundary surfaces of an isotropically consolidated loose sand", Soils and Foundations, 43(2), pp. 89-103 (2003a).

40. Shibuya, S., Hight, D.W., and Jardine, R.J. "Local boundary surfaces of a loose sand dependent on consolidation path", Soils and Foundations, 43(3), pp. 85-93 (2003b).

41. Azami, A., Pietruszczak, S., and Guo, P. "Bearing capacity of shallow foundations in transversely isotropic granular media", International Journal for Numerical and Analytical Methods in Geomechanics, 34(8), pp. 771-793 (2010).

42. Bahadori, H., Ghalandarzadeh, A., and Towhata, I. "Effect of non-plastic silt on anisotropic behaviour of sand", Soil and Foundations, 48(4), pp. 531-545 (2008).

43. Keyhani, R. and Haeri, S.M. "Evaluation of the effect of anisotropic consolidation and principle stress rotation on undrained behaviour of silty sands", Scientia Iranica, 20(6), pp. 1637-1653 (2013).

44. Jafarzadeh, F. and Zamanian, M. "Effect of intermediate principal stress parameter on cyclic behaviour of Sand", Scientia Iranica, 21(5), pp. 1566-1576 (2014).

45. Lade, P., Rodriguez, N., and Van Dyck, E. "Effects of principal stress directions on 3D failure conditions in cross-anisotropic sand", $J$. Geotech. Geoenviron. Eng., 140(2), 04013001 (2014). DOI: http://dx.doi.org/10.1061/(ASCE)GT.19435606.0001005

46. Sadrekarimi, A. "Effect of the mode of shear on static liquefaction analysis", J. Geotech. Geoenviron. Eng., 140(12), 04014069 (2014).

DOI: $10.1061 /($ ASCE)GT.1943-5606.0001182

47. Sadrekarimi, A. "Static liquefaction analysis considering principal stress directions and anisotropy", Geotechnical and Geological Engineering, 34(4), pp. 1135-1154 (2016).

48. Khayat, N., Ghalandarzadeh, N., and Jafari, M.K. "Grain shape effect on the anisotropic behaviour of siltsand mixtures", Proceedings of the ICE - Geotechnical Engineering, 167(3), pp. 281-296 (2012).

49. ASTM "Standard test method for particle-size analysis of soils", D422-63 (2007). http://dx.doi.org/10.1520/D0422-63R07E02 
50. ASTM "Standard test methods for maximum index density and unit weight of soils using a vibratory table", D4253-00 (2003).

http://dx.doi.org/10.1520/D4253-16

51. ASTM "Standard test methods for minimum index density and unit weight of soils and calculation of relative density", D4254-00 (2003).

http://dx.doi.org/10.1520/D4254-16

52. ASTM "Standard test methods for specific gravity of soil solids by water pycnometer", D854-02 (2006). http://dx.doi.org/10.1520/D0854-14

53. Ladd, R.S. "Preparing test specimens using under compaction", Geotechnical Testing Journal, ASTM, $\mathbf{1}(1)$, pp. 16-23 (1978).

54. Hoeg, K., Dyvik, R., and Sandbaekken, G. "Strength of undistrubed versus reconstituted silt and silty sand specimens", Journal of Geotechnical and Geoenvironmental Engineering, 126(7), pp. 606-617 (2000). DOI: 10.1061/(ASCE)1090-0241(2000)126:7(606)

55. Boulanger, R.W., Seed, R.B., Chan, C.K., Seed, H.B., and Sousa, J. "Liquefaction behaviour of saturated sands under unidirectional and bi-directional monotonic and cyclic simple shear loading", Rep. No. UCB/GT/91-08, Univ. of California, Berkeley, Calif. (1991).

56. Polito, C., Green, R., and Lee, J. "Pore pressure generation models for sands and silty soils subjected to cyclic loading", J. Geotech. Geoenviron. Eng., 134(10), pp. 1490-1500 (2008). DOI: 10.1061/(ASCE)1090-0241(2008)134:10(1490)

57. Terzaghi, K., Peck, R.B., and Mesri, G., Soil Mechanics in Engineering Practice, 3rd Ed., London: Wiley (1996).

58. Lee, K.L. and Seed, H.B. "Drained strength characteristics of sands", J. Soil Mech. Found. Div., ASCE, 93(SM6), pp. 117-141 (1967).

59. Negussey, D., Wijewickreme, W.K.D., and Vaid, Y.P. "Constant volume friction angle of granular materials", Can. Geotech. J., 25(1), pp. 50-55 (1988).

60. Been, K. and Jefferies, M.G. "A state parameter for sands", Geotechnique, 35(2), pp. 99-112 (1985). Doi: 10.1680 /geot.1985.35.2.99

61. Wan, R.G. and Guo, R.G. "A pressure and density dependent dilatancy model for granular materials, Soils Found., 39(6), pp. 1-12 (1999).

62. Dietz, M.S. and Lings, M.L. "Postpeak strength of interfaces in a stress-dilatancy framework", J. Geotech. Geoenviron. Engng., 132(11), pp. 1474-1484 (2006).
63. Sadrekarimi, A. and Olson, S.M. "Critical state friction angle of sands", Géotechnique, 61(9), pp. 771-783 (2011).

64. Yang, S.L., Sandven, R., and Grande, L. "Steadystate lines of sand-silt mixtures", Canadian Geotechnical Journal, 43(11), pp. 1213-1219 (2006). Doi: 10.1139/t06-069

65. Mahmood, A. and Mitchell, J.K. "Fabric-property relationships in fine granular materials", Clays and Clay Minerals, 22, pp. 397-408 (1974).

66. Miura, K., Miura, S., and Toki, S. "Deformation behaviour of anisotropic dense sand under principal stress axes rotation", Soils and Foundations, 26(1), pp. 36-52 (1986).

67. Luan, M., Xu, C., He, Y., Guo, Y., Zhang, Z., Jin, D., and Fan, Q. "Experimental study on shear behaviour and an improved constitutive model of saturated sand under complex stress condition", In Proceedings of the Fourth International Conference on Soft Soil Engineering, D.H. Chan and K.T. Law, Eds., CRC Press, Vancouver, Canada, pp. 73-92 (2007).

68. Guo, P. "Modified direct shear test for anisotropic strength of sand", Journal of Geotechnical and Geoenvironmental Engineering, ASCE, 134(9), pp. 13111318 (2008).

69. Towhata, I. and Ishihara, K. "Undrained strength of sand undergoing cyclic rotation of principal stress axes", Soils and Foundations, 25(2), pp. 135-147 (1985).

70. Riemer, M.F. and Seed, R.B. "Factors affecting the apparent position of steady state line", J. Geotech. Geoenviron. Engng, ASCE, 123(3), pp. 281-288 (1997).

71. Cai, Y. "An experimental study of non-coaxial soil behaviour using hollow cylinder testing", Doctoral dissertation, University of Nottingham (2010).

72. Cai, Y., Yu, H.S., Wanatowski, D., and Li, X. "Noncoaxial behaviour of sand under various stress paths", Journal of Geotechnical and Geoenvironmental Engineering, 139(8), pp. 1381-1395 (2012).

73. Logeswaran, P. "Behaviour of sands under generalized loading and drainage conditions", PhD Thesis, Carleton University, Ottawa, Canada, p. 273 (2010).

74. Vipulanantham, M. "Initial stress state and stress history effects on liquefaction susceptibility of Sands", M.Sc. Thesis, Carleton University, Ottawa, Canada, p. 180 (2011).

\section{Biographies}

Fardin Jafarzadeh received his $\mathrm{PhD}$ degree in Civil Engineering from Tohoku University, Japan in 1995 and is currently an Associate Professor of Civil Engineering at Sharif University of Technology, Tehran, Iran. He is the Vice-Chairman of the Iranian Geotechnical Society, and a member of ISSMGE, JSCE, and 
several other professional associations. His research interests include a broad area of topics in Geotechnical and Geotechnical Earthquake Engineering with a special focus on the earth and rockfill dams, ground improvement, physical modeling, and constitutive laws.

Mostafa Zamanian received his $\mathrm{PhD}$ degree in Civil Engineering from Sharif University of Technology (SUT), Tehran, Iran in 2014 and is currently an
Assistant Professor of Civil Engineering at Shahid Beheshti University (SBU). His research interests lie in analytical and numerical analyses of earth and rockfill dams, underground structure, and laboratory investigation of soil characterization. He has professional experiences in designing earth and rockfill dams, deep excavations, tunnels, and site investigations and has teaching experience in SBU and SUT International Campus. 